The International Archives of the Photogrammetry, Remote Sensing and Spatial Information Sciences, Volume XL-1/W5, 2015

International Conference on Sensors \& Models in Remote Sensing \& Photogrammetry, 23-25 Nov 2015, Kish Island, Iran

\title{
DECISION MAKING ON REGIONAL LANDFILL SITE SELECTION IN HORMOZGAN PROVINCE USING SMCE
}

Azadeh Sadat Majedi, MSc. Student, environmental management, Islamic Azad University, Meybod Branch, Iran

BijanMaghsoudlooKamali, assistant professor for Master students of Environmental Management department, Islamic Azad University, Meybod Branch, Iran

RashinMaghsoudi, MSc. Student, environmental pollutions, Islamic Azad University, Meybod Branch, Iran

KEYWORDS: site selection, landfill, environmental decision making, SMCE

\begin{abstract}
Landfill site selection and suitable conditions to bury hazardous wastes are among the most critical issues in modern societies. Taking several factors and limitations into account along with true decision making requires application of different decision techniques. To this end, current paper aims to make decisions about regional landfill site selection in Hormozgan province and utilizes SMCE technique combined with qualitative and quantitative criteria to select the final alternatives. To this respect, we first will describe the existing environmental situation in our study area and set the goals of our study in the framework of SMCE and will analyze the effective factors in regional landfill site selection. Then, methodological procedure of research was conducted using Delphi approach and questionnaires (in order to determine research validity, Chronbach Alpha (0.94) method was used). Spatial multi-criteria analysis model was designed in the form of criteria tree in SMCE using IL WIS software. Prioritization of respective spatial alternatives included: Bandar Abbas city with total 4 spatial alternatives (one zone with $1^{\text {st }}$ priority, one zone with $3^{\text {rd }}$ priority and two zones with $4^{\text {th }}$ priority) was considered the first priority, Bastak city with total 3 spatial alternatives (one zone with $2^{\text {nd }}$ priority, one zone with $3^{\text {rd }}$ priorit and one zone with $4^{\text {th }}$ priority) was the second priority and Bandar Abbas, Minab, Jask and Haji Abad cities were considered as the third priority.
\end{abstract}




\section{Introduction}

One of the significant environmental issues faced by metropolitan areas is management of hazardous urban, industrial and healthcare solid wastes. To this respect, handling healthcare and hazardous waste or special waste are of critical importance becauase lack of correct planning and management may lead to widespread pollution of surface and ground water, soil and air. A basic step in comprehensive management of wastes is to manage special wastes and the main issue in the general procedure of special waste management is landfill site selection (Jandaghian et al, 2012:11). In 2012, Raziyeh Porshokouh, Mohsen Dehghani and Heydar Ghaderi presented an article under title "landfill site selection for urban wastes produced in Haji Abad city using AHP and GIS”.

In current research, from among the existing methods for site selection, we have used a mixed approach of spatial

\section{Material and method}

Methodological phases of this research involve stages, phases and sub-phases designed systematically in order to achieve the main and specified goals as follows:

1- To review useful information resources and records at national and international levels concerning the capabilities of SMCE software in

4- effective criteria in locating regional landfills of special infectious wastes

5- Designing a spatial multi-criteria analysis model in the form of criteria tree in SMCE environment using IL WIS software

6- Mapping and standardization of the criteria affecting regional landfill site selection for special infectious wastes

7- Weighing and prioritization of spatial options and selection of superior spatial options

a) Delphi Questionnaire multi-criteria evaluation (SMCE). As site selection is actually a kind of multi-criteria decision making affecting several indicators to this end, it seems that application of this method can be effective in the process of decision making about regional landfill locations from the standpoint of environmental management. In addition, GIS, being capable of handling a great deal of spatial data from different sources, is ideal for such pilot studies (Nas B, Cay T-2010).

Current study aims to analyze how decisions on suitable sites for establishment of regional landfills are made, investigate the capabilities and limitations of SMCE approach in making decisions about landfill locations, present management methods for reducing pollutions arising from establishment of special infectious waste landfills, achieve sustainable development within the study area and prevent from damage to and pollution of the area by an applied and appropriate site selection.

locating landfills concordant with field investigations of Hormozgan Province landfills.

2- To study the current situation of the environment in the area of study and setting goals for studies within the framework of SMCE approach

3- Identification and selection of the

With regard to those indicators of study that require quantitative analysis to be included into modeling phase, Delphi questionnaire was utilized for public opinion polling.

Delphi method is an approach for collecting experts' opinions and decisions who are not in contact with each other. Delphi method has been used in different research areas related to forecasting the future events (Asgharpour, 2011).

$$
N=\frac{n(n-1)}{2}
$$


Where N: statistical community size: the number case, the sample size was obtained 45 of respective criteria for spatial evaluation of individuals.

regional landfills in Hormozgan Province. In this

Table 1- The main criteria for regional landfill evaluation in Hormozgan province

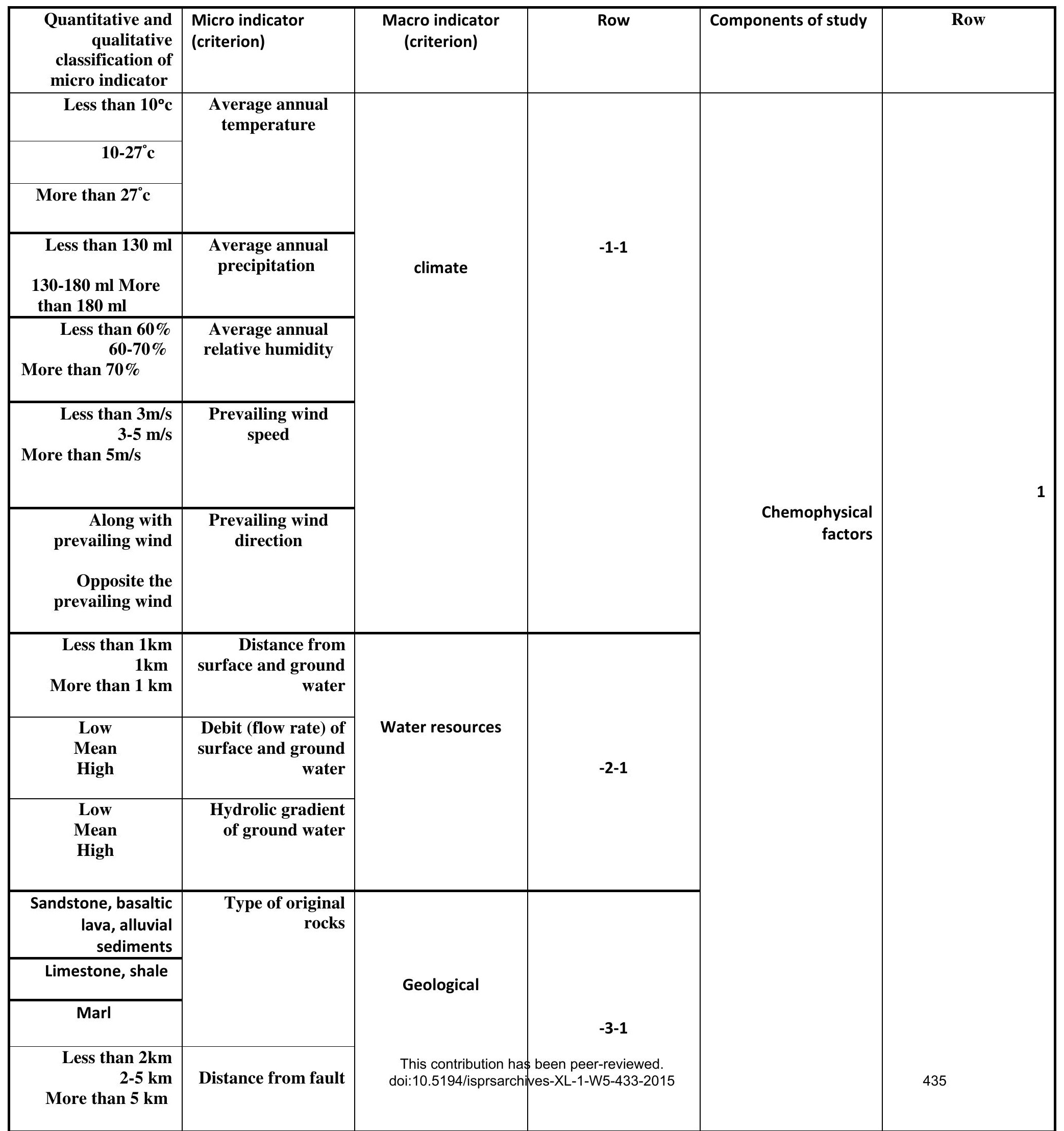




\begin{tabular}{|c|c|c|c|c|c|}
\hline $\begin{array}{r}\text { Less than } 3 \mathrm{~km} \\
3-6 \mathrm{~km} \\
\text { More than } 6 \mathrm{~km} \\
\end{array}$ & $\begin{array}{l}\text { National park } \\
\text { and natural } \\
\text { works }\end{array}$ & & & $\begin{array}{r}\text { Biological } \\
\text { factors }\end{array}$ & 2 \\
\hline $\begin{array}{r}\text { Less than } 1 \mathrm{~km} \\
1-5 \mathrm{~km} \\
\text { More than } 5 \mathrm{~km}\end{array}$ & Protected areas & $\begin{array}{r}\text { Distance from } \\
\text { critical } \\
\text { ecological areas }\end{array}$ & $-2-2$ & & \\
\hline
\end{tabular}

\begin{tabular}{|c|c|c|c|c|c|c|}
\hline $\begin{array}{l}\text { Quantitative } \\
\text { and qualitative } \\
\text { classification of } \\
\text { micro indicator }\end{array}$ & $\begin{array}{c}\text { Micro } \\
\text { indicator } \\
\text { (original sub- } \\
\text { criterion) }\end{array}$ & $\begin{array}{c}\text { Macro } \\
\text { indicator } \\
\text { (original } \\
\text { criterion) }\end{array}$ & Row & $\begin{array}{l}\text { Components of } \\
\text { study }\end{array}$ & Row & \\
\hline $\begin{array}{l}\text { Low } \\
\text { Average } \\
\text { High }\end{array}$ & Air pollution & $\begin{array}{c}\text { Background } \\
\text { and existing } \\
\text { pollutions }\end{array}$ & $-3-1$ & $\begin{array}{c}\text { Environmental } \\
\text { pollution } \\
\text { factors }\end{array}$ & 3 & \\
\hline $\begin{array}{r}\text { Quantitative } \\
\text { and qualitative } \\
\text { classification of } \\
\text { micro indicator }\end{array}$ & $\begin{array}{l}\text { Micro indicator } \\
\text { (original sub- } \\
\text { criterion }\end{array}$ & $\begin{array}{l}\text { Macro indicator } \\
\text { (original } \\
\text { criterion) }\end{array}$ & Row & $\begin{array}{r}\text { Components of } \\
\text { study }\end{array}$ & Row & \\
\hline $\begin{array}{l}\text { Barren } \\
\text { Pasture } \\
\text { Agricultural } \\
\text { Industrial }\end{array}$ & Current use & Land use & $-1-4$ & \multirow{6}{*}{$\begin{array}{l}\text { Socioeconomic } \\
\text { factors }\end{array}$} & \multirow{6}{*}{\multicolumn{2}{|c|}{4}} \\
\hline $\begin{array}{l}\text { Barren } \\
\text { Pasture } \\
\text { Agricultural } \\
\text { Industrial } \\
\end{array}$ & Proposed use & & & & & \\
\hline $\begin{array}{c}\text { Less than } 1 \mathrm{~km} \\
1-2 \mathrm{~km} \\
\text { More than } 2 \\
\mathrm{~km}\end{array}$ & $\begin{array}{r}\text { Distance from } \\
\text { health care } \\
\text { centers }\end{array}$ & \multirow[t]{4}{*}{$\begin{array}{l}\text { Distance from } \\
\text { critical human } \\
\text { and populated } \\
\text { centers }\end{array}$} & \multirow[t]{4}{*}{$-2-4$} & & & \\
\hline $\begin{array}{c}\text { Less than } 1 \mathrm{~km} \\
1-2 \mathrm{~km} \\
\text { More than } 2 \\
\mathrm{~km}\end{array}$ & $\begin{array}{l}\text { Distance from } \\
\text { educational } \\
\text { centers }\end{array}$ & & & & & \\
\hline $\begin{array}{c}\text { Less than } 5 \mathrm{~km} \\
5-10 \mathrm{~km} \\
\text { More than } 10 \\
\text { km }\end{array}$ & $\begin{array}{c}\text { Distance from } \\
\text { urban areas }\end{array}$ & & & & & \\
\hline $\begin{array}{c}\text { Less than } \\
1.5 \mathrm{~km} \\
1.5-5 \mathrm{~km} \\
\text { More than } 5 \\
\text { km }\end{array}$ & $\begin{array}{c}\text { Distance from } \\
\text { rural areas }\end{array}$ & & & & & \\
\hline
\end{tabular}


b) Statistical analysis SPSS

In current work, Chronach's Alpha was used to analyze research reliability which was calculated using the following relation:

$$
\alpha=\frac{k}{k-1}\left[1-\frac{\sum_{i=1}^{k} s_{i}^{2}}{\sigma^{2}}\right]
$$

Reliability of the respective questionnaire was obtained 0.963 , indicating that research reliability has been sufficiently high.

c) Spatial multi-criteria Evaluation (SMCE) model SMCE is a multi-criteria decision model for spatial data. Lots of options can be provided and evaluated in this model. This method is useful for analyzing the impacts of land use planning and regional development. Since SMCE is a structure based on geomatics information, its results are close to reality. Therefore, in studies on site selection of special areas for novel industries, this structure can be applied using IL WIS software to locate appropriate areas. This computer-based program is the spatial type of multicriteria decision methods and enables GISs to analyze data and make decisions. This method resolves the limitation found in GIS in overlaying method concerning the number of layers (Roudgarmi et al, 2008).

According to the conducted analyses and selection of the effective criteria and provision of maps to be used in the model, decision tree for spatial site of regional landfills for special wastes in Hormozgan province was created which is shown in figure 1. 
The International Archives of the Photogrammetry, Remote Sensing and Spatial Information Sciences, Volume XL-1/W5, 2015 International Conference on Sensors \& Models in Remote Sensing \& Photogrammetry, 23-25 Nov 2015, Kish Island, Iran

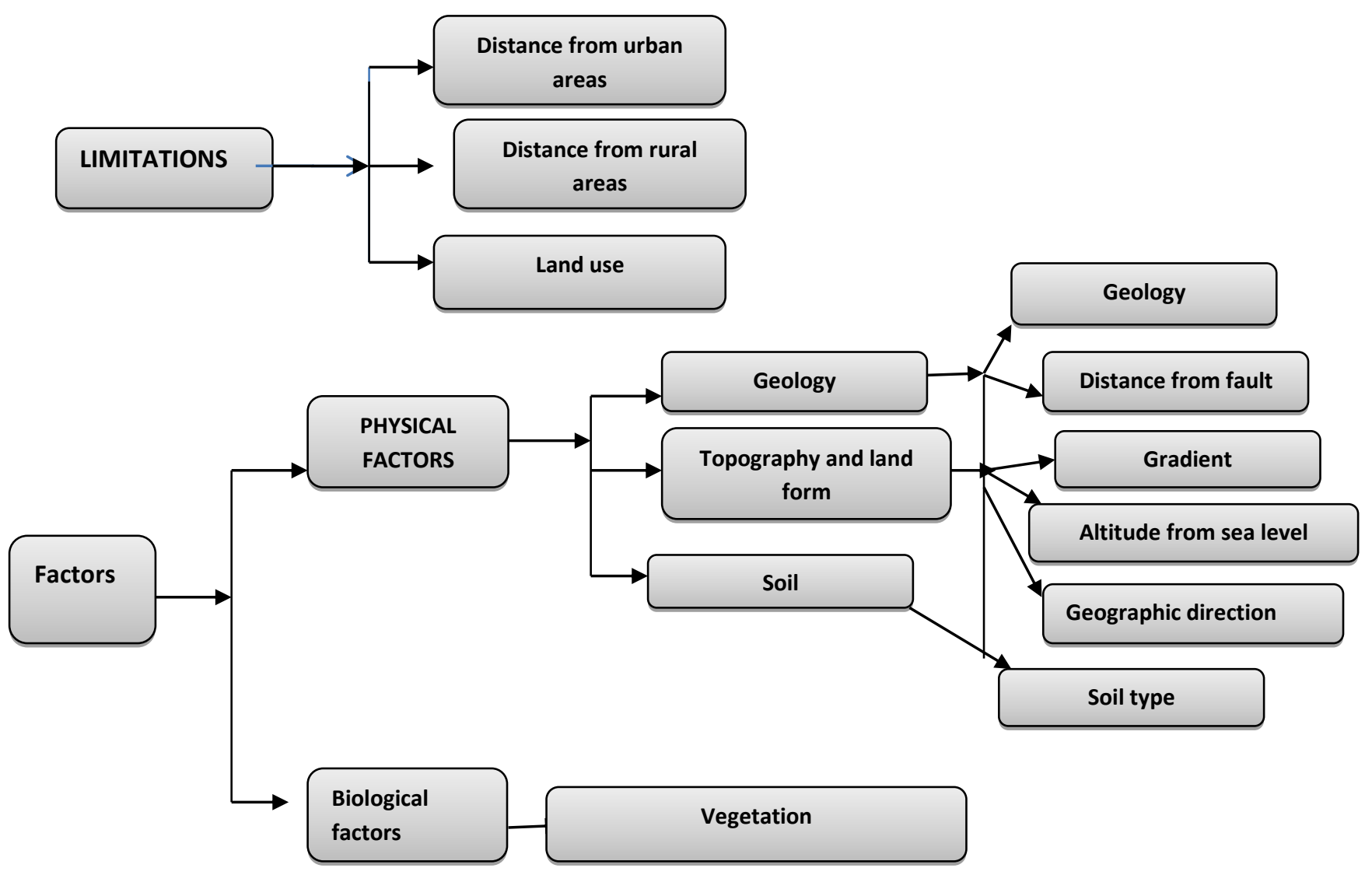

Fig.1- decision tree model 
Result

Findings from studies and research on spatial evaluation of regional landfills for infectious wastes in Hormozgan province are presented in this section including prioritization and weighing of effective criteria on site selection of regional landfills in Expert Choice software and spatial evaluation of regional landfills in Hormozgan province using SMCE model.
With respect to prioritization of the corresponding subcriteria in spatial regional landfill site decision making in Hormozgan province, figure 3 shows that the sub-criteria including temperature 0.174 in weight assumes the first rank, annual relative humidity 0.074 in weight takes the second rank, current land use 0.066 takes the third rank, and distance from educational centers 0.004 in weight takes the lowest and last rank.

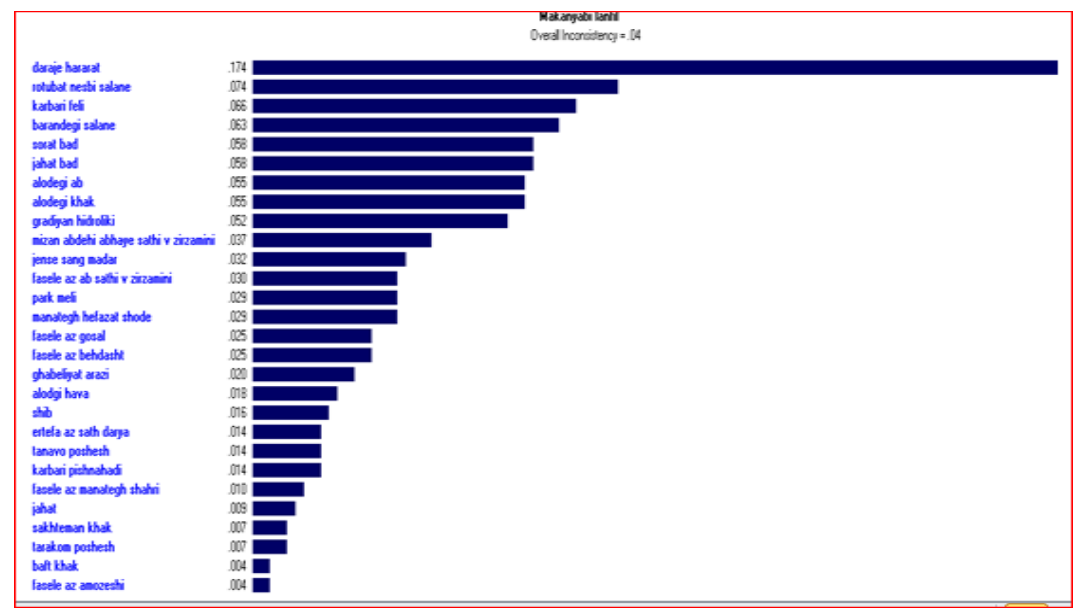

Figure 2- prioritization of subcriteria in spatial decision making on regional landfill sites in hormozgan province

\section{Results of decisions on spatial sites of regional landfills for special infectious wastes using SMCE}

In prioritization of spatial options for regional landfills in Hormozgan province, the results suggest that those sites with value of $0-0.75$ assume the $4^{\text {th }}$ priority followed by areas with value $(0.75-0.80),(0.80-0.85)$ and $(0.85-0.90)$ respectively were assigned the $3^{\text {rd }}, 2^{\text {nd }}$ and $1^{\text {st }}$ spatial priority with the highest value for landfill establishment. Likewise, the results of spatial evaluations conducted in SMCE model indicate that from among cities in Hormozgan province, has the ,Bandar Lengeh with total 4 suitable spatial options largest capacity for landfill establishment followed by Bastak city with total 3 options and Bandar Abbas, Minab, Jask and HajAbad within the next priorities and finally, Rudan City had the lowest capacity for landfill establishment.

Diagram1 shows the final diagram of mixed indicators of landfill site selection in Hormozgan province. 


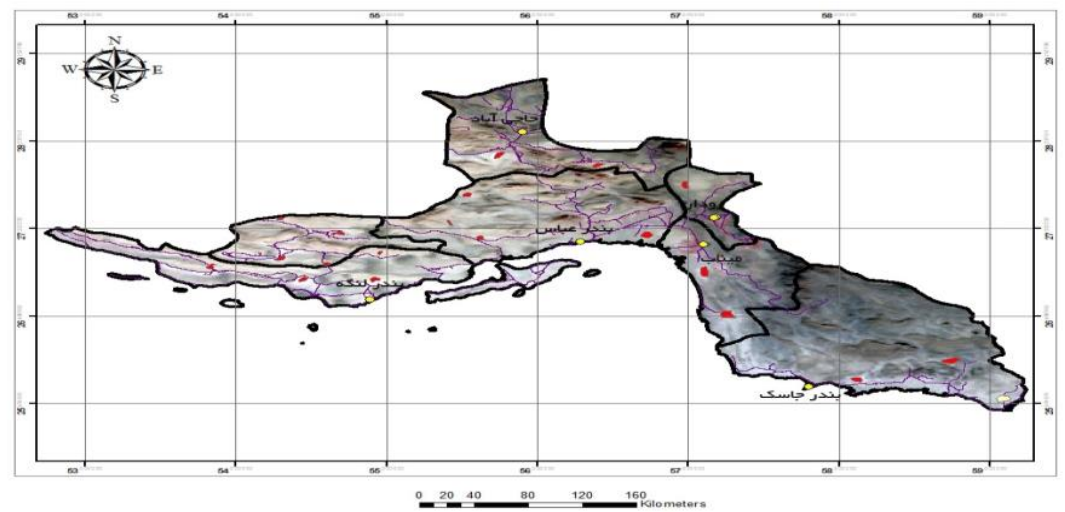

Diagram 1- final diagram of mixed indicators for landfill establishment in Hormozgan province

\section{References}

1-(Maghsoudloo, Bijan, 2008), "principles of planning for methodological procedure of site selection and spatial evaluation of urban landfills (case study of Yazd city), fourth national congress on waste management

2-(Jandaghian, Pooria,2012) Farzaneh Gol Mohammadi,Saeedeh Jalilvand, Methods for Locating Landfills by Using Geographic Information System GIS, the second congress of schematization and environmental management, P. 1-7.

3- (Kaya T, Kahraman,2010) C. Multi-Criteria renewable energy planning using an integrated fuzzy VIKOR \& AHP methodology: The case of Istanbul. Energy ;35(6): 2517-27.

4- (Nas B, Cay T, Iscan F, Berktay,2010) A. Selection of MSW landfill site for Konya, Turkey using GIS and multicriteria evaluation. Environ Monit Assess 2010; 160(1-4): 491-500.

5-(Roudgarmi, Pejman; Khorasani, Nematollah; Monavari, Seyed Masoud; Jafar, Nouri, 2007, ) “assessment of development options for evaluation of environmental impacts using spatial multi-criteria evaluation method", environmental science and technology quarterly, $9^{\text {th }}$ year, No.4 